\title{
Bartosz Ryż
}

\section{Czy James Bond \\ nie dorasta do pięt Achillesowi? Czyli po co komu krytyka literacka}

DOI: http://dx.doi.org/10.12775/LC.2016.044

Streszczenie: W artykule autor rozważa funkcje krytyki literackiej w dzisiejszym społeczeństwie. Przy tej okazji porusza kilka tradycyjnych problemów, które przedstawia w nowych kontekstach, m.in. relacji między kulturą wysoką i niską/popularną, wartościowania przedmiotów uznawanych za estetyczne i tworzenia na ich temat komunikatów oraz umiejscowienia sztuki w systemie społecznym. Formułowane wnioski są odnoszone do wyników analiz dotyczących czytelnictwa w Polsce.

Słowa kluczowe: teoria literatury, krytyka literacka, badania literackie, teoria systemów, konstruktywizm

Abstract. In this article the author considers functions of literary criticism in today's society. He also mentions several traditional problems, but he presents them in new contexts (like relations between high and mass art, evaluation of aesthetic objects and position of art in the social system). Conclusions are compared with the results of analysis of the readership in Poland.

Keywords: literary theory, literary criticism, literary studies, theory of autopoietic systems, constructivism

* Dr, teoretyk literatury, konstruktywista. Redaktor popularnej serii wydawniczej Wiedza o literaturze z punktu widzenia obserwatora oraz tomu Radykalny konstruktywizm. Antologia. Od kilku lat pracuje jako menadżer, zaangażowany w działalność Fundacji Projekt Nauka. E-mail: bartekryz@gmail.com. 
ówienie o sobie jak o kimś, kto książki czyta, jest w modzie. 102 tys. użytkowników Facebooka zadeklarowało, że w 2015 roku przeczyta 52 książki (lub więcej) ${ }^{1}$, facebookowy profil Recenzentka książek dwóch blogerek Gaby i Sylwii „lubi” ponad 145 tys. użytkowników², blog Anny Dutki (wyróżniony w konkursie na Literacki Blog Roku 2015) dziennie potrafi odnotować kilkadziesiąt, a nawet kilkaset wejść ${ }^{3}$. Skoro profil Nie czytasz? Nie idę $z$ Toba do tóżka ma już ponad 153 tys. lajków, to czytać po prostu trzeba.

Badania czytelnictwa nie wskazują jednak na wzrost liczby osób czytających. Powoływanie się na tego typu dane nie jest częstą praktyką w tekstach literaturoznawczych, a przecież nie sposób od nich uciec, jeśli na literaturę i naukę o literaturze patrzeć całościowo, jak na system.

W poniższym tekście centralną rolę odgrywa krytyka literacka, co prowokuje do postawienia kilku nietrywialnych problemów najczęściej trywialnie przedstawianych: relacji między tzw. kulturą wysoką i niską/popularną, wartościowania przedmiotów uznawanych za estetyczne i tworzenia na ich temat komunikatów oraz umiejscowienia sztuki w systemie społecznym. By teoretyczne rozważania, w ramach których będę opisywał te problemy, nie pozostały jedynie wyabstrahowanymi modelami, w toku wywodu co jakiś czas sięgnę do powszechnie dostępnych analiz dotyczących czytelnictwa w Polsce.

System komunikacji estetycznej (według Siegfrieda J. Schmidta) od innych subsystemów społecznych odróżnia się występowaniem konwencji estetycznej w miejscu konwencji faktyczności (znaczy to, że komunikaty estetyczne nie są odnoszone do rzeczywistości) i konwencji poliwalencji w miejscu konwencji monowalencji (zatem zarówno producent, jak i odbiorca komunikatu estetycznego nie są ograniczeni do jednego, jakkolwiek uzgodnionego znaczenia komunikatu $)^{5}$. Choć oba te stwierdzenia wydają się oczywiste w ramach wąskiej grupy czytelników tekstów literaturoznawczych, to zaczynają być sporym problemem, gdy poczynimy błahą obserwację, że sztuka dużo częściej „jest w użyciu” u niespecjalistów niż specjalistów. A niespecjaliści niespecjalnie z tych konwencji (przede wszystkim poliwalencji) zdają sobie sprawę.

Krytyk Anna Arno wspomina w jednym ze swoich tekstów:

Kiedy z przyjaciółmi zwiedzałam kolegiatę w Zamościu, co chwila się upewniali: „Wow czy nie wow? Powinno mi się podobać?” [... ] Pod spodem wyczuwam lęk: „Nie wiem, co artysta chciał powiedzieć. A jeśli coś widzę, to pewnie i tak nie lapię aluzji: lepiej się z tym nie wyrywać..."'.

Powszechna obawa, że mój sąd zwykłego odbiorcy nie pokryje się z sądem znawcy (krytyk Arno), który jednocześnie jest uznawany za obowiązujący (przekonanie o mono-

\footnotetext{
1 Zob. https://www.facebook.com/events/315561018642822 (dostęp 31.10.2015).

2 Zob. https://www.facebook.com/Recenzentka-ksi\%C4\%85\%C5\%BCek-531155103668925/?fref=ts (dostęp 31.10.2015).

3 Zob. http://recenzentka.blox.pl/html (dostęp 31.10.2015).

${ }_{4}$ Zob. https://www.facebook.com/nieczytasz (dostęp 31.10.2015).

5 Zob. B. Balicki, Empiryczna nauka o literaturze - kierunek w badaniach literackich i szkoła naukowa, „Teksty Drugie" 2010, nr 4, s. 42.

6 A. Arno, Sztuka nie gryzie „,Gazeta Wyborcza” z 29-30 sierpnia 2015, s. 42.
} 
walencji), hamuje potencjał poliwalencji. Do tego aspektu jeszcze wrócę, ale przytaczam tę krótką anegdotę już teraz, ponieważ mówi ona znacznie więcej o funkcji, jaką pełni krytyka sztuki (w tym literatury) niż klasyczny tekst Janusza Sławińskiego ${ }^{7}$. Sławiński wprawdzie pisze o wartościowaniu jako jednej z trzech podstawowych funkcji krytyki literackiej, ale nie odnosi się do szerszego kontekstu społecznego - po co społeczeństwu oceny dzieł sztuki dokonywane przez ekspertów?

By na to kluczowe pytanie odpowiedzieć, sięgnę ponownie do teorii systemu literackiego Schmidta, z której wyłania się struktura systemu literackiego oparta o cztery elementarne role działań: produkcję, pośrednictwo, recepcję i przetwarzanie komunikatów literac$\mathrm{kich}^{8}$. Krytyka literacka przynależy do działań związanych z przetwarzaniem literatury: to krytycy, poprzez oferowanie czytelnikom matryc interpretacyjnych dla konkretnych utworów, wskazują, ja k c z y t a ć. Tym samym jednak wskazują przecież i to, c o c z y t a ć, a zatem pełnią aktywną rolę w kształtowaniu się rynku literackiego - przede wszystkim dzięki obecności funkcji poznawczo-oceniającej. I tutaj pojawia się drugi moment, w którym Schmidtowski model natrafia na analogiczne trudności, jak jego pomysł na wyodrębnienie konwencji estetycznej. Otóż z pewnością wnikliwa, kilkustronicowa recenzja w „Odrze” czy „Akcencie” oddziałuje na środowisko literatów i specjalistów od literatury, ale jej wpływ na to, co „zadzieje się” wśród czytelników-niespecjalistów (a więc wśród ogromnej większości uczestników systemu literackiego), jest żaden, bo kilkutysięczne nakłady siłą rzeczy nie wychodzą poza środowisko. Można by podejrzewać, że aby uchwycić ten wpływ, należy sięgnąć po krytykę pojawiającą się w prasie wysokonakładowej: co innego 100 tys. egzemplarzy „Polityki”, a co innego kilkaset sztuk „Odry”, co innego wykład dla kilkunastu osób i kawiarniane rozmowy, a co innego przegląd prasy w mainstreemowych mediach. Tym bardziej że akurat recenzje w prasie popularnej pod względem funkcji oceniającej stworzyły narzędzie, które wydaje się niemożliwe do przecenienia przy tak masowej komunikacji, a mianowicie czytelne i jednoznaczne wartościowanie w postaci $\mathbf{\square} \mathbf{m} \mathbf{\square} \square$ (z różnymi wariantami, od gwiazdek po emotikony) 9 .

By zweryfikować powyższe tezy, posłużę się kilkoma źródłami danych, zaczynając od raportu Instytutu Książki.

\footnotetext{
7 J. Sławiński, Funkcje krytyki literackiej, „Twórczość" 1962, nr 8.

8 B. Balicki, op. cit., s. 39.

9 Tego typu wartościowanie graficzne jest zabiegiem obiektywizującym ocenę, ale w samych tekstach recenzji z prasy masowej często podkreślana jest ich subiektywna strona („Jeśli ktoś, jak ja, lubi klimaty...”). Z kolei recenzje z prasy specjalistycznej elementy obiektywizujące mają najczęściej wpisane w swoją strukturę (wyjawianie powiązań intertekstualnych, odkrywanie subtelnej gry z tradycją literacką itd.), co ma prowadzić do konkluzji, że przedstawiona ocena nie jest tylko subiektywnym oglądem dzieła dokonanym przez konkretnego krytyka. Różnic jest zresztą na tyle dużo, że można tu mówić o dwóch oddzielnych gatunkach i szczegółowe porównanie odmiennych stylów tych dwóch typów recenzji byłoby z pewnością ciekawym ćwiczeniem genologicznym - nie to jest jednak przedmiotem prezentowanego artykułu.
} 
Tabela 1 (wg analizy Rynek książki w Polsce Instytutu Książki, 2014)

\begin{tabular}{|c|c|}
\hline Bestsellery roku 2013 w kategorii 'Fikcja' & Bestsellery roku 2013 w kategorii 'Non-fiction' \\
\hline $\begin{array}{l}\text { Nowe oblicze Greya, E. L. James, przeł. Monika } \\
\text { Wiśniewska, liczba sprzedanych egzemplarzy: } \\
\qquad 356000 \text { (Sonia Draga) }\end{array}$ & $\begin{array}{l}\text { Dowód, Eben Alexander, przeł. Rafał Śmietana, } \\
\text { liczba sprzedanych egzemplarzy: } 100000 \text { (Znak) }\end{array}$ \\
\hline $\begin{array}{l}\text { Inferno, Dan Brown, przet. Robert J. Szmidt, liczba } \\
\text { sprzedanych egzemplarzy: } 320000 \text { (Sonia Draga) }\end{array}$ & $\begin{array}{c}\text { Boks na ptaku, Maria Czubaszek, Artur Andrus, } \\
\text { Wojciech Karolak, liczba sprzedanych egzemplarzy: } \\
79000 \text { (Prószyński Media) }\end{array}$ \\
\hline $\begin{array}{c}\text { Pięćdziesiąt twarzy Greya, E. L. James, przeł. } \\
\text { Monika Wiśniewska, liczba sprzedanych egzempla- } \\
\text { rzy: } 244000 \text { (Sonia Draga) }\end{array}$ & $\begin{array}{l}\text { Kronos, Witold Gombrowicz, liczba sprzedanych } \\
\text { egzemplarzy: } 60000 \text { (Wydawnictwo Literackie) }\end{array}$ \\
\hline $\begin{array}{l}\text { Wiedźmin - sezon burz, Andrzej Sapkowski, liczba } \\
\text { sprzedanych egzemplarzy: } 214000 \text { (SuperNowa) }\end{array}$ & $\begin{array}{c}\text { Flirtujac z życiem, Danuta Stenka, Łukasz } \\
\text { Maciejewski, liczba sprzedanych egzemplarzy: } \\
50000 \text { (Znak) }\end{array}$ \\
\hline $\begin{array}{l}\text { Ciemniejsza strona Greya, E. L. James, przeł. Monika } \\
\text { Wiśniewska, liczba sprzedanych egzemplarzy: } \\
144000 \text { (Sonia Draga) }\end{array}$ & $\begin{array}{c}\text { Trochę większy poniedziatek, Katarzyna Grochola, } \\
\text { liczba sprzedanych egzemplarzy: } 50000 \\
\text { (Wydawnictwo Literackie) }\end{array}$ \\
\hline $\begin{array}{l}\text { Houston mamy problem, Katarzyna Grochola, } \\
\text { liczba sprzedanych egzemplarzy: } 135000 \\
\text { (Wydawnictwo Literackie) }\end{array}$ & $\begin{array}{c}\text { Kalendarz niematżeński, Paulina Młynarska, Dorota } \\
\text { Wellman, liczba sprzedanych egzemplarzy: } \\
50000 \text { (Znak) }\end{array}$ \\
\hline $\begin{array}{l}\text { Zgoda na szczéście, Anna Ficner-Ogonowska, liczba } \\
\text { sprzedanych egzemplarzy: } 85000 \text { (Znak) }\end{array}$ & $\begin{array}{c}\text { The Top Gear Years, Jeremy Clarkson, przel. Michał } \\
\text { Strąkow, liczba sprzedanych egzemplarzy: } \\
48000 \text { (Insignis) }\end{array}$ \\
\hline $\begin{array}{c}\text { Bezcenny, Zygmunt Miłoszewski, liczba sprzeda- } \\
\text { nych egzemplarzy: } 80000 \text { (W.A.B.) }\end{array}$ & $\begin{array}{l}\text { W krzywym zwierciadle, Maciej Stuhr, liczba sprze- } \\
\text { danych egzemplarzy: } 35000 \text { (Zwierciadło) }\end{array}$ \\
\hline $\begin{array}{l}\text { Doktor sen, Stephen King, przeł. Tomasz Wilusz, } \\
\text { liczba sprzedanych egzemplarzy: } \\
77000 \text { (Prószyński Media) }\end{array}$ & $\begin{array}{c}\text { Tańczaca Eurydyka. Anna German we wspomnie- } \\
\text { niach, Mariola Pryzwan, liczba sprzedanych } \\
\text { egzemplarzy: } 30000 \text { (PIW) }\end{array}$ \\
\hline $\begin{array}{l}\text { Alibi na szczęście, Anna Ficner-Ogonowska, liczba } \\
\text { sprzedanych egzemplarzy: } 70000 \text { (Znak) }\end{array}$ & $\begin{array}{c}\text { Niełatwy dzień, Mark Owen, przeł. Łukasz Małecki, } \\
\text { liczba sprzedanych egzemplarzy: } \\
30000 \text { (Wydawnictwo Literackie) }\end{array}$ \\
\hline
\end{tabular}

Wszystkie pozycje z tabeli 1 pojawiły się w recenzjach najpopularniejszych dzienników i tygodników. Nawet Gombrowicz, ze względu na charakter Kronosu, był szeroko komentowany w prasie wysokonakładowej, gdzie poświęcono mu chyba nawet więcej miejsca niż w publikacjach literaturoznawców. Jakie recenzje pojawiły się w 2013 roku, przykładowo, w „Akcencie” (jedno z reprezentatywnych czasopism, w których pojawia się „krytyka specjalistyczna” - tak będę dalej roboczo określał teksty krytycznoliterackie pojawiające się w czasopiśmiennictwie branżowym, by odróżnić je od tekstów krytycznych pojawiających się w prasie masowej)? 
Tabela 2 (Recenzje, które pojawiły się „Akcencie” w 2013 roku)

\begin{tabular}{|c|c|}
\hline „Akcent”, nr 1, 2013 & „Akcent”, nr 2, 2013 \\
\hline $\begin{array}{c}\text { Marcin Klimowicz: Ledwie widoczne sznurki } \\
{[\text { Karol Maliszewski, Manekiny }]}\end{array}$ & $\begin{array}{c}\text { Małgorzata Szlachetka: „Ghetto Boy” multiplikowany } \\
\text { [Frédéric Rousseau, Żydowskie dziecko z Warszawy. } \\
\text { Historia pewnej fotografii }]\end{array}$ \\
\hline $\begin{array}{l}\text { Edyta Ignatiuk: Totemy i fetysze } \\
\text { [Andrzej Stasiuk, Grochów] }\end{array}$ & $\begin{array}{c}\text { Andrzej Molik: Teatr reżysera. Teatr krytyka } \\
\text { [Elżbieta Baniewicz }\{\text { Dziwny_czas }\} \text { Szkice o teatrze } \\
\text { z lat 2000-2012] }\end{array}$ \\
\hline $\begin{array}{l}\text { Andrzej Goworski: Książka jak sweter poloni- } \\
\text { sty? [Waldemar Bawołek, Humoreska] }\end{array}$ & $\begin{array}{c}\text { Henryk Waniek: Na łąkach stów [Leszek Mądzik, } \\
\text { Obrazy bez tytułu] }\end{array}$ \\
\hline $\begin{array}{l}\text { Małgorzata Szlachetka: Co mają zombie do holo- } \\
\text { kaustu? [Igor Ostachowicz, Noc żywych Żydów] }\end{array}$ & $\begin{array}{c}\text { Jarosław Cymerman: Przygody Leśmiana Żeglarza } \\
\text { [Bogusław Grodzki, Leśmianowska baśń } \\
\text { nowoczesna. O „Przygodach Sindbada Żeglarza” } \\
\text { Bolestawa Leśmiana] }\end{array}$ \\
\hline $\begin{array}{c}\text { Agnieszka Kida-Bosek: Kryształowy Pałac } \\
\text { [Dorota Masłowska, Kochanie, zabiłam nasze koty] }\end{array}$ & $\begin{array}{c}\text { Iwona Hofman: „Nikt mi go nie zastapit” [ Juliusz } \\
\text { Mieroszewski, Listy } z \text { Wyspy. ABC polityki } \\
\text { „Kultury”] }\end{array}$ \\
\hline $\begin{array}{l}\text { Przemysław Kaliszuk: Ciężar habitu } \\
\text { [Tadeusz Chabrowski, Białe nieszpory] }\end{array}$ & $\begin{array}{c}\text { Karol Maliszewski: Kończyć to na nowo zaczynać... } \\
\text { [Od(nowa) - znowu - na nowo. Rekapitulacja, } \\
\text { red. Jarosław Wach, Łukasz Janicki }]\end{array}$ \\
\hline & $\begin{array}{l}\text { Paweł Mackiewicz: Niepewny ślad rzeczy } \\
\text { [Andrzej Niewiadomski, Dzikie lilie] }\end{array}$ \\
\hline & $\begin{array}{c}\text { Ewa Dunaj: Pierwszy stopień do piekła } \\
\text { [Grzegorz Jędrek, Badland }]\end{array}$ \\
\hline & $\begin{array}{c}\text { Edyta Antoniak-Kiedos: Sprawna, jeszcze nie zawsze } \\
\text { stateczna [Magdalena Jankowska, Skrzyżowanie] }\end{array}$ \\
\hline & $\begin{array}{c}\text { Agata Ptak: „Stowa dostatem za darmo” [Wasyl } \\
\text { Machno, Dubno, koto Leżajska. Wiersze i poematy] }\end{array}$ \\
\hline & $\begin{array}{l}\text { Anna Spólna: Jeszcze jeden "fragment" } \\
\text { [Tadeusz Różewicz, to i owo }]\end{array}$ \\
\hline „Akcent”, nr 3, 2013 & „Akcent”, nr 4, 2013 \\
\hline $\begin{array}{l}\text { Bartłomiej Krupa: Cień zagłady [Następstwa } \\
\text { zagłady Żydów. Polska 1944-2010, red. Feliks Tych, } \\
\text { Monika Adamczyk-Garbowska] }\end{array}$ & $\begin{array}{l}\text { Edyta Ignatiuk: Przywracanie pamięci [Oksana } \\
\text { Zabużko, Muzeum porzuconych sekretów] }\end{array}$ \\
\hline $\begin{array}{l}\text { Małgorzata Szlachetka: Dehnel nie rozmienia się na } \\
\text { drobne [Jacek Dehnel, Młodszy księgowy. } \\
\text { O książkach, czytaniu i pisaniu] }\end{array}$ & $\begin{array}{c}\text { Aleksander Wójtowicz: Safari } \\
\text { w Mordorze [Ziemowit Szczerek, Przyjdzie Mordor } \\
\text { i nas zje, czyli tajna historia Stowian] }\end{array}$ \\
\hline $\begin{array}{c}\text { Marcin Orliński: W stanie rozproszenia [Arkadiusz } \\
\text { Bagłajewski, Mapy dwudziestolecia 1989-2009. } \\
\text { Linie ciaggtości] }\end{array}$ & $\begin{array}{c}\text { Ewelina Stanios: Ulepiony z żeńskiej gliny } \\
\text { [Szczepan Twardoch, Morfina }]\end{array}$ \\
\hline $\begin{array}{l}\text { Dominika Kurek: Polskie smoki i polscy ryce- } \\
\text { rze [Małgorzata Tkacz, Baśnie zbyt prawdziwe. } \\
\text { Trzydzieści lat fantasy w Polsce] }\end{array}$ & $\begin{array}{l}\text { Ewa Dunaj: Specjalistka od operacji na otwartym } \\
\text { sercu? [Kaja Malanowska, Patrz na mnie, Klaro!] }\end{array}$ \\
\hline $\begin{array}{l}\text { Karolina Ewa Wieliczko: Zawsze (poza) } \\
\text { fragment [Jacek Łukasiewicz, TR] }\end{array}$ & $\begin{array}{c}\text { Marcin Klimowicz: } \\
\text { Niewiadomszczyzna [Andrzej Niewiadomski, } \\
\text { Mapa. Prolegomena] }\end{array}$ \\
\hline
\end{tabular}


Cd tab. 2

\begin{tabular}{|c|c|}
\hline „Akcent”, nr 3, 2013 & „Akcent”, nr 4, 2013 \\
\hline $\begin{array}{c}\text { Rafał Czekaj: Erudyta na szańcach kultury maso- } \\
\text { wej [Umberto Eco, Po drugiej stronie lustra } i \text { inne } \\
\text { eseje] }\end{array}$ & $\begin{array}{l}\text { Wiesława Turżańska: Między Pólnoca } \\
\text { a Południem [Jan Władysław Woś, Sympozjum } \\
\text { w Cassino i inne opowiadania] }\end{array}$ \\
\hline \multirow[t]{6}{*}{$\begin{array}{l}\text { Arkadiusz Bagłajewski: Obecność romanty- } \\
\text { zmu [Magdalena Rabizo-Birek, Romantyczni } \\
\text { i nowocześni. Formy obecności romantyzmu w polskiej } \\
\text { literaturze wspótczesnej] }\end{array}$} & $\begin{array}{l}\text { Małgorzata Rygielska: Bliskość [Jarosław } \\
\text { Mikołajewski, Na wdechu] }\end{array}$ \\
\hline & $\begin{array}{c}\text { Anna Butrym: Niepokorny ironista } \\
\text { [Géza Szőcs, Poezje] }\end{array}$ \\
\hline & $\begin{array}{c}\text { Joanna Kisiel: Na krzyż [Kazimierz Brakoniecki, } \\
\text { Chiazma] }\end{array}$ \\
\hline & $\begin{array}{c}\text { Sławomir Jacek Żurek: Podwójność [Anna Frajlich, } \\
\text { Łodzia jest i jest przystania] }\end{array}$ \\
\hline & $\begin{array}{l}\text { Marcin Orliński: } W \text { ciaglym ruchu } \\
\text { [Kamil Brewiński, Clubbing] }\end{array}$ \\
\hline & $\begin{array}{c}\text { Michał Piętniewicz: Możliwości dialogu } \\
\text { [Eda Ostrowska, Echolalie] }\end{array}$ \\
\hline
\end{tabular}

Dodatkowo, poniżej podaję listę laureatów najważniejszych nagród literackich w Polsce w 2013 roku, zakładając, że będą to autorzy wyjątkowo docenieni przez krytykę specjalistyczną:

- Nagroda literacka Nike: Ciemno, prawie noc, Joanna Bator

- Nagroda Literacka Gdynia:

$>$ w kategorii proza: Ocalenie Atlantydy, Zyta Orszyn

w kategorii poezja: Sylwetki i cienie, Andrzej Sosnowski

186 w kategorii esej: Opis krainy Gog, Marian Sworzeń

- Literacka Nagroda Europy Środkowej ANGELUS: Muzeum porzuconych sekretów, Oksana Zabużko

- Nagroda Fundacji im. Kościelskich: Krystyna Dąbrowska

- Paszport Polityki: Ziemowit Szczerek

Jak widać, rozbieżność między pozycjami/autorami omawianymi i docenianymi przez gremia wewnątrzśrodowiskowe i tymi faktycznie czytanymi, jest całkowita. Autorytet krytyka-specjalisty, co i rusz mamy na to dowody, oddziałuje na środowisko literackie, ale to jest zbyt wąskie, by miało bezpośredni wpływ na to, co czyta kilkaset czy kilkadziesiąt tysięcy ludzi. Nawet jeśli dzieło uhonorowane przez środowisko po otrzymaniu nagrody sprzedaje się lepiej, wzrost najczęściej nie jest na tyle duży, by faktycznie wpłynął na rynek czytelniczy $^{10}$. Na poziomie krytyki specjalistycznej nie ma więc mowy o funkcji kształtującej rynek literacki. Jak zatem uzasadnić jej istnienie?

10 Oczywiście nie oznacza to, że zawsze mieliśmy do czynienia z taką sytuacją. Jeszcze w latach 80. i 90. pozytywna recenzja książki w „Fantastyce" czy "Nowej Fantastyce” (czyli, jakby nie było, w prasie specjalistycznej) niemal gwarantowała jej osiągnięcie statusu bestsellera. Fenomen literatury science fiction to jednak przypadek specyficzny - patrz: M. Urban, Fantastyka naukowa w Polsce jako subkultura, [w:] Metateoretyczne problemy litera- 
Odpowiedź - jeśli przyjmiemy wewnątrzsystemowy punkt widzenia - jest w miarę oczywista. Krytyka specjalistyczna istnieje, ponieważ jest pretekstem do kontynuowania komunikacji w ramach systemu i tym samym zapewnia temu systemowi (literackiemu) trwanie (zresztą zupełnie analogicznie, jak sama literatura czy badania literackie). Wydaną książkę można zrecenzować, na to z kolei można odpowiedzieć recenzją polemiczną, w sytuacji dyskusji - gdy dzieło budzi tak różnorakie emocje - głos może zabrać autor, dając z kolei pretekst do kolejnych odpowiedzi krytykom. A ostatecznie wszystko to zostanie opisane w ramach tego, co nazywamy historią literatury. Dodatkowo to przecież krytycy, nawet jeśli niekiedy tylko pośrednio, decydują w dużej mierze o tym, co jest czytane w szkole czy wznawiane w ramach serii popularyzujących klasykę.

Jak jednak uzasadnić zapotrzebowanie na krytykę w najpopularniejszych dziennikach i tygodnikach? Wprawdzie lista wyborów lekturowych Polaków z tabeli 1 pokrywa się z listą najczęściej omawianych książek w mediach masowych, trudno jednak na tej podstawie wyciągnąć jednoznacznie wniosek, że czytelnicy wprost kierowali się dokonaną tam oceną. Czy bestsellery byłyby bestsellerami bez ich promowania w prasie wysokonakładowej? By w pełni i precyzyjnie odpowiedzieć, potrzebna byłaby analiza rynku sięgająca do metod i narzędzi badań marketingowych. W tym momencie chciałbym poprzestać na przytoczeniu wyników innego badania - raportu Biblioteki Narodowej Stan czytelnictwa w Polsce w 2014 roku (autorzy to: Izabela Koryś, Dominika Michalak, Roman Chymkowski). Jednym z zadań dla ankietowanych było pytanie o źródła lekturowych rekomendacji (wśród czytelników, którzy zadeklarowali przeczytanie przynajmniej jednej książki w roku).

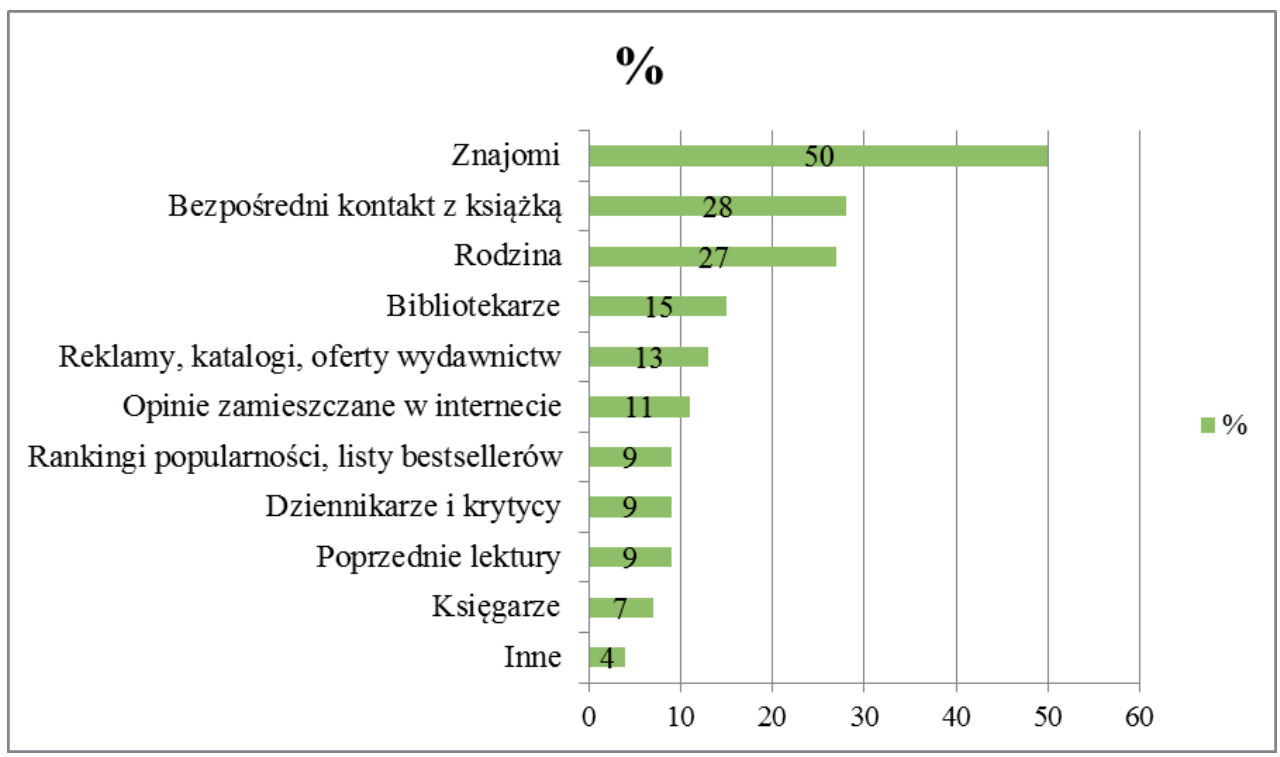

Wykres 1 (TNS dla Biblioteki Narodowej, 2014)11

turoznawcze. Wiedza o literaturze z punktu widzenia obserwatora, red. B. Balicki, D. Lewiński, B. Ryż, E. Szczerbuk, Wrocław 2005, s. 157-167.

11 Wykres obrazuje dane zawarte w raporcie Biblioteki Narodowej, który opracowano na podstawie sondażu TNS Polska. Badanie przeprowadzono na przełomie listopada i grudnia 2014 roku na próbie 3000 respondentów (Polacy w wieku 15 lat i więcej). 
Okazuje się, że opinią krytyki literackiej kieruje się ledwie 9\% ankietowanych, na pewno więc nie należy jej (i to obojętnie już w jakiej wersji, bardziej specjalistycznej czy masowej) traktować jako istotnego czynnika mającego wpływ na rynek czytelniczy. Być może krytycy kształtują elitarny rynek malarski, ale w przypadku tak egalitarnych form, jak kino czy literatura, wydaje się, że to już nie działa.

Cofnijmy się teraz na bardziej podstawowy poziom. W koncepcji społeczeństwa funkcjonalnie zróżnicowanego Niklasa Luhmanna istnienie oddzielnego systemu sztuki jest co najmniej problematyczne, choć o samej sztuce niemiecki socjolog pisał nader często ${ }^{12}$. Być może jednak problemy te związane są z przyjętym przez Luhmanna kodowaniem, które tworzy według niego sztukę. Kod odpowiada za to, jak konkretny system określa sam siebie, czyli jak rozpoznaje możliwość wewnątrzsystemowego łączenia rozmaitych operacji i jak - dzięki temu - na bieżąco produkuje i reprodukuje rozróżnienie system-otoczenie ${ }^{13}$. Piękno $\leftrightarrow$ brzydota, czyli kodowanie przyjęte przez Luhmanna dla sztuki, przynajmniej od naturalizmu, jest rozróżnieniem wątpliwym. Natomiast jeśliby w tym momencie wyciągnąć wnioski z anegdoty przywoływanej przez Arno, wydaje się, że śmiało można przyjąć inny nadrzędny, binarny kod sztuki: wa r t o ś c i o w e $\leftrightarrow$ be z w a r t o ś c i o w e.

Zauważmy, że kodowanie wartościowe $\leftrightarrow$ bezwartościowe aktualizuje reguły medium komunikacyjnego gospodarki, czyli pieniądza, choćby poprzez działanie mechanizmu popytu i podaży, który decyduje o faktycznej wartości danego towaru. Nadanie sztuce (lub odebranie) wartości w paradoksalny sposób ją urynkawia i w pewnym sensie sytuuje w systemie gospodarczym: dzieło sztuki przestaje być dobrem samym w sobie i staje się, lepszym lub gorszym, produktem. Choć oczywiście reguły działania tego rynku mogą być (i są) zupełnie inne od tych, które obowiązują tam, gdzie podchodzimy do rynku rutynowo. Ciekawym tego przykładem jest efekt polegający na nietraceniu-na-wartości (w opisywanym tu rozumieniu) dzieł sztuki. Jeśli Iliada została uznana za arcydzieło wszech czasów, zostanie nim właśnie po wsze czasy - i choć przygody Flemingowskiego Bonda nęcą nieporównanie bardziej niż dokonania Achillesa, a i pod kątem psychologicznym agent 007 jest zdecydowanie bardziej skomplikowany, to nigdy nie dorośnie do pięt Homeryckiemu bohaterowi ${ }^{14}$. Jeśli zasada jedności miejsca, czasu i akcji jest (całkiem słusznie) utożsamiana z mistrzowskim opanowaniem warsztatu dramaturgicznego, to przecież nikt dziś nie powie, że dla współczesnego odbiorcy, żyjącego w innym zupełnie świecie i mającego zdecydowanie większe możliwości percepcyjne, jest ona tylko nudnym ograniczeniem. Proces anektowania przez system sztuki kolejnych fenomenów jest powszechnie znany: kalendarz Majów, ale też ogromne nieużywane fabryki, magazyny i składy zasiedlone przez artystów, którzy odnaleźli tam przestrzeń zapewniającą swobodę tworzenia i życia - czyli lofty, stały się dziełami sztuki. Czy coś może przestać być dziełem sztuki? Nie wydaje się, dla m.in. tych przypadków wymyślono slogan „Tylko dla koneserów”.

Inne reguły rynku sztuki w stosunku do pozostałych dziedzin gospodarki, w tym inne reguły wartościowania, pomaga wyjaśnić koncepcja Pierre’a Bourdieu ${ }^{15}$, która dodatkowo

12 E. Kuźma, Sztuka w perspektywie operacyjnego konstruktywizmu N. Luhmanna, „Teksty Drugie” 2010, nr 4, s. 15-29.

13 Zob. N. Luhmann, Die Realität der Massenmedien, Opladen 1996, s. 31-47.

14 Por. U. Eco, Struktury narracyjne u Fleminga, [w:] idem, Superman w literaturze masowej. Powieść popularna: między retoryka a ideologiq, Kraków 2008, s. 192-246.

15 P. Bourdieu, J. C. Passeron, Reprodukcja. Elementy teorii systemu nauczania, przeł. E. Neyman, Warszawa 2006. 
rzuca wiele światła na kilka z powyżej przedstawionych tez oraz pozwala sformułować kilka kolejnych. Kluczowym pojęciem tej teorii jest kapitał, który służy Bourdieu do opisania całości systemu społecznego. Występują trzy rodzaje kapitału: ekonomiczny, społeczny i kulturowy. W ramach kapitału kulturowego pozytywnie wartościowane są zjawiska, które np. z punktu widzenia kapitału ekonomicznego są bezwartościowe, jak choćby oczytanie. Pole produkcji kapitału kulturowego, w ramach wewnętrznych reguł, odrzuca pieniądz jako wyznacznik sukcesu, jednak by tego rodzaju kapitał mógł być wykorzystywany w praktyce, konieczne jest ograniczenie do niego dostępu, tak jak ograniczany jest dostęp do pieniądza - nie miałoby sensu posiadanie kapitału jakiegokolwiek typu, gdyby każdy w łatwy sposób mógł go zdobyć. To dzieje się poprzez specyficzny język, który - w przypadku literatury - zawłaszcza ten obszar i przyczynia się do powstania podstawowego rozróżnienia na tych, którzy posiadają kompetencje do jego używania, i pozostałych. Ponadto język tworzy kolejne rozróżnienie, na sztukę wysoką i niską. „O ile odbiór produktów »komercyjnych « jest prawie całkowicie niezależny od poziomu wykształcenia konsumentów, o tyle »czyste « dzieła sztuki dostępne są tylko tym, którzy mają odpowiednie przygotowanie i kompetencje, niezbędne do ich oceny" ${ }^{\prime 6}$. Nie godzi się, ale też i nie ma sensu, żeby krytyka specjalistyczna dotyczyła dzieł, o których może rozmawiać każdy. Z kolei krytyka w mediach masowych stosuje, mówiąc o sztuce, kodowanie wartościowe $\leftrightarrow$ bezwartościowe przeformułowane na bardziej przyjazne masowemu odbiorcy: nowatorskie $\leftrightarrow$ wtórne, ambitne $\leftrightarrow$ banalne czy, być może najczęściej dziś stosowane, wciągające $\leftrightarrow$ nudne.

Pojawienie się kapitału kulturowego stworzyło nową hierarchię społeczną, podzieliło społeczeństwo na intelektualistów „i tych, którzy woleli powiększać swój kapitał ekonomiczny. Jako że podział ten stanowił pewnego rodzaju przetworzenie prastarych opozycji ducha i materii, duszy i ciała, intelektualiści zajęli w nim pozycję wyższą, ponieważ związani byli z wartościami dawno uznanymi” ${ }^{17}$. Wynikające stąd przekonanie o wyższości sądu znawcy nad własną opinią czyni komunikację o sztuce jedną z mniej demokratycznych dziedzin i niweczy w dużej mierze potencjał poliwalencji.

Spójrzmy teraz na jeszcze jedne wyniki badań. TNS, na zlecenie Biblioteki Narodowej, zapytało ankietowanych m.in. o ich wybory lekturowe.

Tabela 3 (Wybory lekturowe polskich czytelników: TNS dla Biblioteki Narodowej, 2014)

\begin{tabular}{|c|c|}
\hline $\begin{array}{c}15 \text { najczęściej wymienianych autorów } \\
\text { wg popularności }\end{array}$ & $\begin{array}{l}15 \text { najczęściej wymienianych tytułów książek } \\
\text { bądź serii wydawniczych wg popularności }\end{array}$ \\
\hline 1. Henryk Sienkiewicz & 1. E. L. James - seria o Greyu \\
\hline 2. Dan Brown & 2. Stieg Larsson - seria Millenium \\
\hline 3. Stephen King & 3. Pismo Święte Starego i Nowego Testamentu \\
\hline 4. Andrzej Sapkowski & 4. Henryk Sienkiewicz - Ogniem i mieczem \\
\hline 5. Harlan Coben & 5. George R. R. Martin - Gra o tron \\
\hline
\end{tabular}

16 P. Bourdieu, Reguły sztuki. Geneza i struktura pola literackiego, przeł. A. Zawadzki, Kraków 2001, s. 228.

17 B. Palus, Upadek schizmy kulturowej? O poziomach kultury z punktu widzenia obserwatora II stopnia, [w:] Anatomia dyskursu. Wiedza o literaturze z punktu widzenia obserwatora III, red. B. Balicki, B. Ryż, E. Szczerbuk, Wrocław 2008, s. 266. 
Cd tab. 3

\begin{tabular}{|l|l|}
\hline $\begin{array}{c}\text { 15 najczęściej wymienianych autorów } \\
\text { wg popularności }\end{array}$ & \multicolumn{1}{|c|}{$\begin{array}{c}\mathbf{1 5} \text { najczęściej wymienianych tytulów książek } \\
\text { bądź serii wydawniczych wg popularności }\end{array}$} \\
\hline 6. George R. R. Martin & 6. J. R. R. Tolkien - Hobbit \\
\hline 7. Paulo Coelho & 7.J. K. Rowling - seria o Harrym Potterze \\
\hline 8. Agata Christie & 8. Dan Brown - Kod Leonarda da Vinci \\
\hline 9. Joanna Chmielewska & 9. Bolesław Prus - Lalka \\
\hline 10. E. L. James & 10. Helen Fielding - seria o Bridget Jones \\
\hline 11. Danielle Steel & 11. Aleksander Kamiński - Kamienie na szaniec \\
\hline 12. Katarzyna Grochola & 12. Henryk Sienkiewicz - Krzyżacy \\
\hline 13. Camilla Lackberg & 13. Carlos Ruiz Zafon - Cień Wiatru \\
\hline 14. Katarzyna Michalak & 14. Waris Dirie, Cathleen Miller - Kwiat pustyni \\
\hline 15. J. R. R. Tolkien & 15. Michaił Bułhakow - Mistrz i Małgorzata \\
\hline
\end{tabular}

Pamiętajmy, że w tym badaniu mamy do czynienia z deklaracjami czytelniczymi. Badanie przeprowadzono w 2014 roku, więc śmiało można założyć, że odpowiedzi odnosiły się do doświadczeń przede wszystkim z ostatniego roku i tym samym można je porównać z przytaczanym wcześniej zestawieniem Instytutu Książki, które pokazywało faktyczne zachowanie konsumentów-czytelników. Listy w pewnym stopniu się pokrywają (Brown, Grochola, James, King, Sapkowski), sporo pozycji to tytuły, które bardzo często pojawiały się w mediach (Gra o tron, seria Millenium). Z kolei część nazwisk i tytułów z tabeli 3 padła zapewne dlatego, że tylko ci autorzy i te książki były znane ankietowanym (na co bez wątpienia w dużym stopniu wpłynął obowiązek szkolny): Bułhakow, Prus, Sienkiewicz. Pięćdziesiąt twarzy Greya to absolutny top zarówno jeśli chodzi o czytelnicze deklaracje, jak i faktyczne wybory. Książka ta w recenzjach, w najlepszym wypadku, określana była jako może i wciągająca, ale bez większych ambicji. Co jednak najciekawsze, jest ona oceniona jedynie na 5,8 gwiazdki na 10 możliwych na popularnym portalu lubimyczytac.pl (średnia z prawie 30000 dokonanych ocen) przez samych czytelników. Jeśli komunikację, jako szczególną formę interakcji, traktować jako „wzajemne odnoszenie się do siebie aktorów poprzez oczekiwania co do zachowań innych osób oraz antycypujące oczekiwanie oczekiwań co do własnego zachowania"18, to gusta estetyczne będą niczym innym, jak konstrukcją własnego wizerunku. O sztuce mówię to, co myślę, że będzie pozytywnie wpływało na ten wizerunek, nie tylko podczas odpowiadania na pytania zadawane przez ankietera zajmującego się badaniem opinii publicznej, ale także - a może zwłaszcza - w codziennej rozmowie z przyjaciólmi. Niebezpiecznie jest zatem wysoko oceniać coś, co przez fachowców cenione nie jest. I po to - wracając do pytania postawionego w tytule - jest krytyka literacka: żeby było wiadomo, co o konkretnych książkach mówić. Nawet, jeśli się ich nie czytało.

18 K-J. Tillman, Teorie socjalizacji. Społeczność, instytucja, upodmiotowienie, przeł. G. Bluszcz, B. Miracki, Warszawa 1996, s. 143-144. 


\section{Bibliografia}

Arno Anna, Sztuka nie gryzie, „Gazeta Wyborcza” z 29-30 sierpnia 2015.

Balicki Bogdan, Empiryczna nauka o literaturze - kierunek w badaniach literackich i szkoła naukowa, „Teksty Drugie” 2010, nr 4.

Bourdieu Pierre, Reguly sztuki. Geneza i struktura pola literackiego, przeł. A. Zawadzki, Kraków: Universitas, 2001.

Bourdieu Pierre, Passeron Jean-Claude, Reprodukcja. Elementy teorii systemu nauczania, przeł. E. Neyman, Warszawa: Wydawnictwo Naukowe PWN, 2006.

Eco Umberto, Struktury narracyjne u Fleminga, [w:] idem, Superman $w$ literaturze masowej. Powieść popularna: między retoryka a ideologią, Kraków: Znak, 2008.

Kuźma Erazm, Sztuka w perspektywie operacyjnego konstruktywizmu N. Luhmanna, „Teksty Drugie” 2010, $\mathrm{nr} 4$.

Luhmann Niklas, Die Realität der Massenmedien, Opladen: Westdeutscher Verlag, 1996.

Palus Berenika, Upadek schizmy kulturowej? O poziomach kultury $z$ punktu widzenia obserwatora II stopnia, [w: ] Anatomia dyskursu. Wiedza o literaturze z punktu widzenia obserwatora III, red. B. Balicki, B. Ryż, E. Szczerbuk, Wrocław: ATUT, 2008.

Sławiński Janusz, Funkcje krytyki literackiej, „Twórczość” 1962, nr 8.

Tillman Klaus-Jürgen, Teorie socjalizacji. Społeczność, instytucja, upodmiotowienie, przeł. G. Bluszcz, B. Miracki, Warszawa: Wydawnictwo Naukowe PWN, 1996.

Urban Marcin, Fantastyka naukowa w Polsce jako subkultura, [w: ] Metateoretyczne problemy literaturoznawcze. Wiedza o literaturze z punktu widzenia obserwatora, red. B. Balicki, D. Lewiński, B. Ryż, E. Szczerbuk, Wrocław: ATUT, 2005. 